Editorial

\title{
Approach of Serial Crystallography
}

\section{Ki Hyun Nam $\mathbb{D}$}

Department of Life Science, Pohang University of Science and Technology, Pohang, Gyeongbuk 37673, Korea; structures@postech.ac.kr

Received: 21 September 2020; Accepted: 22 September 2020; Published: 23 September 2020

\begin{abstract}
Radiation damage and cryogenic sample environment are an experimental limitation observed in the traditional X-ray crystallography technique. However, the serial crystallography (SX) technique not only helps to determine structures at room temperature with minimal radiation damage, but it is also a useful tool for profound understanding of macromolecules. Moreover, it is a new tool for time-resolved studies. Over the past 10 years, various sample delivery techniques and data collection strategies have been developed in the SX field. It also has a wide range of applications in instruments ranging from the $X$-ray free electron laser (XFEL) facility to synchrotrons. The importance of the various approaches in terms of the experimental techniques and a brief review of the research carried out in the field of SX has been highlighted in this editorial.
\end{abstract}

Keywords: serial crystallography (SX); serial femtosecond crystallography (SFX); serial millisecond crystallography (SMX); serial synchrotron crystallography (SSX); sample delivery

X-ray crystallography helps to observe macromolecules at an atomic resolution [1]. The X-ray technique is useful to understand chemical and biological processes and the functions of various target molecules [2]. The obtained structural information provides insight into the development of new drugs, and it enables protein engineering, which can develop proteins with various industrial applications [2-5]. Hence, the traditional X-ray crystallography research technique has significantly contributed to the development in the field of academics, medicine, and various other industries.

However, data collection process using the conventional X-ray crystallography technique with a single crystal has technical limitations, such as radiation damage and maintenance of a cryogenic environment [6]. The determination of the macromolecule structure at room temperature or the optimum temperature for activity is ideal and biologically important. However, X-ray diffraction data collection performed at room temperature causes K-shell photo-ionization and Auger decay of the macromolecule $[7,8]$. This leads to generation of an electron cascade by electron-impact ionization $[9,10]$. Accordingly, various radical reactions, such as redox processes, free radical generation, and chemical bond breakage, also occur $[9,11,12]$. Moreover, it can cause conformational changes in the macromolecular or crystal lattice $[10,13]$. Thus, radiation damage not only reduces diffraction intensity but also leads to changes in the $R_{\text {merge }}$ or unit cell [14]. To reduce radiation damage, cryocrystallographic methods have been widely used during diffraction data collection in studies related to macromolecule crystallography $[15,16]$. Cryogenic data collection reduces the rate of radiation damage and extends the life of the crystal when exposed to X-rays [17]. Moreover, compared to non-cryogenic data collection, thermal disorder can be reduced and X-rays can be exposed for a longer time; thus, better resolution can be achieved by increasing the diffraction intensity in a crystal-stable manner [17]. However, the process of cooling the crystal not only causes lattice distortion, but also increases the mosaic spread [15-17]. Moreover, radiation damage can still occur at cryogenic temperatures, as the cryogenic temperature warms up during X-ray exposure and the total motion and diffusion of water and other small molecules take place [18,19]. When the molecular species is not trapped, the exposed crystals crack, and bubbles are formed. The resulting gas expands, thereby causing the disruption of the crystal lattice $[18,19]$. 
Moreover, the crystal structure determined at cryogenic temperatures is less flexible than that at room temperature [20,21]. Therefore, the process followed in traditional X-ray crystallographic techniques can sometimes determine structures that are less biologically relevant [22,23].

Serial crystallography is a technique that can overcome the experimental limitations observed in the traditional X-ray technique $[6,24,25]$. SX uses X-ray free electron laser (XFEL) or synchrotron X-ray, wherein the crystals are exposed to the $X$-rays only once, thus minimizing radiation damage compared to the traditional X-ray crystallography technique. Moreover, these experiment approaches allow data collection at room temperature [26].

Serial femtosecond crystallography (SFX) using XFEL provides an extremely high peak brilliance and an ultrashort pulse width at a femtosecond jitter, thereby providing an opportunity to implement not only SX data collection using small crystal samples but also to enable a markedly short time-scaled pump-probe study [6,27]. Thus, SX using XFEL is beneficial for time-resolved studies using micron or sub-micron crystals. However, owing to the structure of the XFEL facility for XFEL production, the supply of beam time cannot meet the demand. As an alternative to this technique, serial millisecond crystallography (SMX) or serial synchrotron crystallography (SSX) based on synchrotron X-rays has been recently used [28-32]. In order to perform the SX using synchrotron X-rays, it is important not only to provide a high photon flux at the sample position but also to enable fast readout by a detector [33]. Currently, many macromolecule crystallography beamlines at synchrotrons have achieved X-ray focusing using optics (e.g., K-B mirror) by up to a few microns and high-speed readout detectors are commercially available. Therefore, it is expected that several SX-related studies will utilize more synchrotrons in the near future.

The process of collecting diffraction data by exposing the crystal to X-rays in SX is the same as that observed in the traditional X-ray crystallography technique. However, because X-rays are only exposed to the crystal volume in the SX experiment, determination of the three-dimensional structure will require a large number of crystals to collect diffraction data [26]. Moreover, a sample delivery method is required to continuously and reliably deliver a large number of crystal samples to the X-ray interaction point for diffraction data collection [34,35]. Various sample delivery methods such as the use of injectors [36,37], syringes [38,39], injection with carrier matrix [35,37-44], fixed-target scanning [33,45-48], microfluidics [49-51], and conveyor belt approaches [52,53] are developed. These techniques are used to carry out the SX experiment and crystal structure can be determined successfully.

The sample delivery method is selected based on the characteristics of the crystal, crystallization solution, amount of crystal, and the purpose of the study. Moreover, the method is selected according to the specifications of the sample delivery device and the facility in which the SX is carried out. Currently, there are five X-ray XFEL facilities that carry out SFX, namely, Linac Coherent Light Source (LCLS) [54], SPring-8 Angstrom Compact Free Electron Laser Facility (SACLA) [55], Pohang Accelerator Laboratory X-ray Free Electron Laser (PAL-XFEL) [56], European XFEL [57], and SwissFEL [58]. In SFX, beamline is performed in these XFEL facilities, and the sample environment (vacuum, He, or ambient air), beam characteristics (repetition rate, photon flux, beam size, pulse width, and so on), and other devices (detector, optical laser, and so on) are different. Moreover, various experimental devices (injector, translation stage, and crystal support for fixed-target scanning) are applied to deliver samples. In SSX or SMX using synchrotron X-rays, sample delivery devices, beam characteristics (photon flux and beam size), detector (specification and readout speed), and sample environment (temperature and air path) vary in each beamline. As a result, research approaches vary according to the specifications and characteristics of the experimental hutch that performs SX and the devices that deliver the sample.

In the early stages of SX research, sample delivery and data collection strategies based on injectors were common; however, now diverse sample delivery methods and data collection strategies have been reported $[26,33-35,59,60]$. Although the SX research approach used by each facility cannot be applied in the same manner to all other facilities, reporting and sharing of SX approaches followed in each research institute and facility will provide new insights to the SX community in the future 
and provide useful information for development of a universal system that can be easily accessed by general researchers.

Funding: This work was funded by the National Research Foundation of Korea (NRF) grant funded by the Korean government (MOE) (NRF-2017M3A9F6029736).

Conflicts of Interest: The author declares no conflict of interest. The funders had no role in the design of the study; in the collection, analyses, or interpretation of data; in the writing of the manuscript, or in the decision to publish the results.

\section{References}

1. Parker, M.W. Protein Structure from X-ray Diffraction. J. Biol. Phys. 2003, 29, 341-362. [CrossRef] [PubMed]

2. Ennifar, E. X-ray Crystallography as a Tool for Mechanism-of-Action Studies and Drug Discovery. Curr. Pharm. Biotechnol. 2013, 14, 537-550. [CrossRef] [PubMed]

3. Cooper, D.R.; Porebski, P.J.; Chruszcz, M.; Minor, W. X-ray crystallography: Assessment and validation of protein-small molecule complexes for drug discovery. Expert Opin. Drug Discov. 2011, 6, 771-782. [CrossRef] [PubMed]

4. Müller, H.; Becker, A.K.; Palm, G.J.; Berndt, L.; Badenhorst, C.P.S.; Godehard, S.P.; Reisky, L.; Lammers, M.; Bornscheuer, U.T. Sequence-Based Prediction of Promiscuous Acyltransferase Activity in Hydrolases. Angew. Chem. Int. Ed. 2020, 59, 11607-11612. [CrossRef] [PubMed]

5. Wu, S.; Snajdrova, R.; Moore, J.C.; Baldenius, K.; Bornscheuer, U. Biocatalysis: Enzymatic Synthesis for Industrial Applications. Angew. Chem. Int. Ed. 2020. [CrossRef]

6. Boutet, S.; Lomb, L.; Williams, G.J.; Barends, T.R.M.; Aquila, A.; Doak, R.B.; Weierstall, U.; DePonte, D.P.; Steinbrener, J.; Shoeman, R.L.; et al. High-Resolution Protein Structure Determination by Serial Femtosecond Crystallography. Science 2012, 337, 362-364. [CrossRef]

7. Lomb, L.; Barends, T.R.M.; Kassemeyer, S.; Aquila, A.; Epp, S.W.; Erk, B.; Foucar, L.; Hartmann, R.; Rudek, B.; Rolles, D.; et al. Radiation damage in protein serial femtosecond crystallography using an $\mathrm{x}$-ray free-electron laser. Phys. Rev. B 2011, 84. [CrossRef]

8. Chapman, H.N.; Fromme, P.; Barty, A.; White, T.A.; Kirian, R.A.; Aquila, A.; Hunter, M.S.; Schulz, J.; DePonte, D.P.; Weierstall, U.; et al. Femtosecond X-ray protein nanocrystallography. Nature 2011, 470, 73-77. [CrossRef]

9. Warkentin, M.; Hopkins, J.B.; Badeau, R.; Mulichak, A.M.; Keefe, L.J; Thorne, R.E. Global radiation damage: Temperature dependence, time dependence and how to outrun it. J. Synchrotron. Radiat. 2012, 20, 7-13. [CrossRef] [PubMed]

10. Nass, K. Radiation damage in protein crystallography at X-ray free-electron lasers. Acta Crystallogr. Sect. D Struct. Biol. 2019, 75, 211-218. [CrossRef] [PubMed]

11. Weik, M.; Ravelli, R.B.G.; Kryger, G.; McSweeney, S.; Raves, M.L.; Harel, M.; Gros, P.; Silman, I.; Kroon, J.; Sussman, J.L. Specific chemical and structural damage to proteins produced by synchrotron radiation. Proc. Natl. Acad. Sci. USA 2000, 97, 623-628. [CrossRef] [PubMed]

12. Meents, A.; Dittrich, B.; Gutmann, S. A new aspect of specific radiation damage: Hydrogen abstraction from organic molecules. J. Synchrotron Radiat. 2009, 16, 183-190. [CrossRef] [PubMed]

13. Garman, E.F. Radiation damage in macromolecular crystallography: What is it and why should we care? Acta Crystallogr. Sect. D Biol. Crystallogr. 2010, 66, 339-351. [CrossRef] [PubMed]

14. Sliz, P.; Harrison, S.C.; Rosenbaum, G. How does Radiation Damage in Protein Crystals Depend on X-ray Dose? Structure 2003, 11, 13-19. [CrossRef]

15. Pflugrath, J.W. Practical macromolecular cryocrystallography. Acta Crystallogr. Sect. F Struct. Biol. Commun. 2015, 71, 622-642. [CrossRef]

16. Garman, E.F.; Owen, R.L. Cryocooling and radiation damage in macromolecular crystallography. Acta Crystallogr. Sect. D Biol. Crystallogr. 2005, 62, 32-47. [CrossRef]

17. Rodgers, D.W. Cryocrystallography. Structure 1994, 2, 1135-1140. [CrossRef] 
18. Teng, T.-Y.; Moffat, K. Primary radiation damage of protein crystals by an intense synchrotron X-ray beam. J. Synchrotron Radiat. 2000, 7, 313-317. [CrossRef]

19. Meents, A.; Gutmann, S.; Wagner, A.; Schulze-Briese, C. Origin and temperature dependence of radiation damage in biological samples at cryogenic temperatures. Proc. Natl. Acad. Sci. USA 2009, 107, 1094-1099. [CrossRef]

20. Weinert, T.; Olieric, N.; Cheng, R.; Brunle, S.; James, D.; Ozerov, D.; Gashi, D.; Vera, L.; Marsh, M.; Jaeger, K.; et al. Serial millisecond crystallography for routine room-temperature structure determination at synchrotrons. Nat. Commun. 2017, 8, 542. [CrossRef]

21. Fraser, J.S.; van den Bedem, H.; Samelson, A.J.; Lang, P.T.; Holton, J.M.; Echols, N.; Alber, T. Accessing protein conformational ensembles using room-temperature X-ray crystallography. Proc. Natl. Acad. Sci. USA 2011, 108, 16247-16252. [CrossRef] [PubMed]

22. Weik, M.; Ravelli, R.B.G.; Silman, I.; Sussman, J.L.; Gros, P.; Kroon, J. Specific protein dynamics near the solvent glass transition assayed by radiation-induced structural changes. Protein Sci. 2001, 10, 1953-1961. [CrossRef] [PubMed]

23. Matsui, Y.; Sakai, K.; Murakami, M.; Shiro, Y.; Adachi, S.; Okumura, H.; Kouyama, T. Specific damage induced by $\mathrm{X}$-ray radiation and structural changes in the primary photoreaction of bacteriorhodopsin. J. Mol. Biol. 2002, 324, 469-481. [CrossRef]

24. Martin-Garcia, J.M.; Conrad, C.E.; Coe, J.; Roy-Chowdhury, S.; Fromme, P. Serial femtosecond crystallography: A revolution in structural biology. Arch. Biochem. Biophys. 2016, 602, 32-47. [CrossRef] [PubMed]

25. Fromme, P.; Graves, W.S.; Martin-Garcia, J.M. Serial Femtosecond Crystallography: A Decade at the Forefront in Structural Biology. eLS 2020, 1-17. [CrossRef]

26. Martiel, I.; Muller-Werkmeister, H.M.; Cohen, A.E. Strategies for sample delivery for femtosecond crystallography. Acta Cryst. D Struct. Biol. 2019, 75, 160-177. [CrossRef]

27. Kim, J.; Kim, H.Y.; Park, J.; Kim, S.; Kim, S.; Rah, S.; Lim, J.; Nam, K.H. Focusing X-ray free-electron laser pulses using Kirkpatrick-Baez mirrors at the NCI hutch of the PAL-XFEL. J. Synchrotron Radiat. 2018, 25, $289-292$. [CrossRef]

28. Gati, C.; Bourenkov, G.; Klinge, M.; Rehders, D.; Stellato, F.; Oberthur, D.; Yefanov, O.; Sommer, B.P.; Mogk, S.; Duszenko, M.; et al. Serial crystallography on in vivo grown microcrystals using synchrotron radiation. IUCrJ 2014, 1, 87-94. [CrossRef]

29. Stellato, F.; Oberthur, D.; Liang, M.; Bean, R.; Gati, C.; Yefanov, O.; Barty, A.; Burkhardt, A.; Fischer, P.; Galli, L.; et al. Room-temperature macromolecular serial crystallography using synchrotron radiation. IUCrJ 2014, 1, 204-212. [CrossRef]

30. Botha, S.; Nass, K.; Barends, T.R.; Kabsch, W.; Latz, B.; Dworkowski, F.; Foucar, L.; Panepucci, E.; Wang, M.; Shoeman, R.L.; et al. Room-temperature serial crystallography at synchrotron X-ray sources using slowly flowing free-standing high-viscosity microstreams. Acta Cryst. D Biol. Cryst. 2015, 71, 387-497. [CrossRef]

31. Owen, R.L.; Axford, D.; Sherrell, D.A.; Kuo, A.; Ernst, O.P.; Schulz, E.C.; Miller, R.J.D.; Mueller-Werkmeister, H.M. Low-dose fixed-target serial synchrotron crystallography. Acta Crystallogr. Sect. D Struct. Biol. 2017, 73, 373-378. [CrossRef]

32. Weinert, T.; Skopintsev, P.; James, D.; Dworkowski, F.; Panepucci, E.; Kekilli, D.; Furrer, A.; Brunle, S.; Mous, S.; Ozerov, D.; et al. Proton uptake mechanism in bacteriorhodopsin captured by serial synchrotron crystallography. Science 2019, 365, 61-65. [CrossRef] [PubMed]

33. Park, S.-Y.; Choi, H.; Eo, C.; Cho, Y.; Nam, K.H. Fixed-Target Serial Synchrotron Crystallography Using Nylon Mesh and Enclosed Film-Based Sample Holder. Crystals 2020, 10, 803. [CrossRef]

34. Zhao, F.Z.; Zhang, B.; Yan, E.K.; Sun, B.; Wang, Z.J.; He, J.H.; Yin, D.C. A guide to sample delivery systems for serial crystallography. FEBS J. 2019, 286, 4402-4417. [CrossRef]

35. Nam, K.H. Sample Delivery Media for Serial Crystallography. Int. J. Mol. Sci. 2019, 20, 1094. [CrossRef]

36. DePonte, D.P.; Weierstall, U.; Schmidt, K.; Warner, J.; Starodub, D.; Spence, J.C.H.; Doak, R.B. Gas dynamic virtual nozzle for generation of microscopic droplet streams. J. Phys. D Appl. Phys. 2008, 41. [CrossRef]

37. Weierstall, U.; James, D.; Wang, C.; White, T.A.; Wang, D.J.; Liu, W.; Spence, J.C.H.; Doak, R.B.; Nelson, G.; Fromme, P.; et al. Lipidic cubic phase injector facilitates membrane protein serial femtosecond crystallography. Nat. Commun. 2014, 5, 3309. [CrossRef] 
38. Sugahara, M.; Mizohata, E.; Nango, E.; Suzuki, M.; Tanaka, T.; Masudala, T.; Tanaka, R.; Shimamura, T.; Tanaka, Y.; Suno, C.; et al. Grease matrix as a versatile carrier of proteins for serial crystallography. Nat. Methods 2015, 12, 61-63. [CrossRef] [PubMed]

39. Park, S.Y.; Nam, K.H. Sample delivery using viscous media, a syringe and a syringe pump for serial crystallography. J. Synchrotron. Radiat. 2019, 26, 1815-1819. [CrossRef] [PubMed]

40. Conrad, C.E.; Basu, S.; James, D.; Wang, D.; Schaffer, A.; Roy-Chowdhury, S.; Zatsepin, N.A.; Aquila, A.; Coe, J.; Gati, C.; et al. A novel inert crystal delivery medium for serial femtosecond crystallography. IUCrJ 2015, 2, 421-430. [CrossRef] [PubMed]

41. Park, J.; Park, S.; Kim, J.; Park, G.; Cho, Y.; Nam, K.H. Polyacrylamide injection matrix for serial femtosecond crystallography. Sci. Rep. 2019, 9, 2525. [CrossRef] [PubMed]

42. Nam, K.H. Shortening injection matrix for serial crystallography. Sci. Rep. 2020, 10, 107. [CrossRef] [PubMed]

43. Nam, K.H. Polysaccharide-Based Injection Matrix for Serial Crystallography. Int. J. Mol. Sci. 2020, $21,3332$. [CrossRef]

44. Nam, K.H. Lard Injection Matrix for Serial Crystallography. Int. J. Mol. Sci. 2020, 21, 5977. [CrossRef]

45. Hunter, M.S.; Segelke, B.; Messerschmidt, M.; Williams, G.J.; Zatsepin, N.A.; Barty, A.; Benner, W.H.; Carlson, D.B.; Coleman, M.; Graf, A.; et al. Fixed-target protein serial microcrystallography with an X-ray free electron laser. Sci. Rep. 2014, 4, 6026. [CrossRef]

46. Roedig, P.; Ginn, H.M.; Pakendorf, T.; Sutton, G.; Harlos, K.; Walter, T.S.; Meyer, J.; Fischer, P.; Duman, R.; Vartiainen, I.; et al. High-speed fixed-target serial virus crystallography. Nat. Methods 2017, 14, 805-810. [CrossRef]

47. Lee, D.; Baek, S.; Park, J.; Lee, K.; Kim, J.; Lee, S.J.; Chung, W.K.; Lee, J.L.; Cho, Y.; Nam, K.H. Nylon mesh-based sample holder for fixed-target serial femtosecond crystallography. Sci. Rep. 2019, 9, 6971. [CrossRef]

48. Lee, K.; Lee, D.; Baek, S.; Park, J.; Lee, S.J.; Park, S.; Chung, W.K.; Lee, J.-L.; Cho, H.-S.; Cho, Y.; et al. Viscous-medium-based crystal support in a sample holder for fixed-target serial femtosecond crystallography. J. Appl. Crystallogr. 2020, 53, 1051-1059. [CrossRef]

49. Monteiro, D.C.F.; Vakili, M.; Harich, J.; Sztucki, M.; Meier, S.M.; Horrell, S.; Josts, I.; Trebbin, M. A microfluidic flow-focusing device for low sample consumption serial synchrotron crystallography experiments in liquid flow. J. Synchrotron. Radiat. 2019, 26, 406-412. [CrossRef]

50. Calvey, G.D.; Katz, A.M.; Pollack, L. Microfluidic Mixing Injector Holder Enables Routine Structural Enzymology Measurements with Mix-and-Inject Serial Crystallography Using X-ray Free Electron Lasers. Anal. Chem. 2019. [CrossRef] [PubMed]

51. Nam, K.H. Stable sample delivery in viscous media via a capillary for serial crystallography. J. Appl. Cryst. 2020, 53, 45-50. [CrossRef]

52. Beyerlein, K.R.; Dierksmeyer, D.; Mariani, V.; Kuhn, M.; Sarrou, I.; Ottaviano, A.; Awel, S.; Knoska, J.; Fuglerud, S.; Jönsson, O.; et al. Mix-and-diffuse serial synchrotron crystallography. IUCrJ 2017, 4, 769-777. [CrossRef] [PubMed]

53. Fuller, F.D.; Gul, S.; Chatterjee, R.; Burgie, E.S.; Young, I.D.; Lebrette, H.; Srinivas, V.; Brewster, A.S.; Michels-Clark, T.; Clinger, J.A.; et al. Drop-on-demand sample delivery for studying biocatalysts in action at X-ray free-electron lasers. Nat. Methods 2017, 14, 443-449. [CrossRef] [PubMed]

54. Emma, P.; Akre, R.; Arthur, J.; Bionta, R.; Bostedt, C.; Bozek, J.; Brachmann, A.; Bucksbaum, P.; Coffee, R.; Decker, F.J.; et al. First lasing and operation of an angstrom-wavelength free-electron laser. Nat. Photonics 2010, 4, 641-647. [CrossRef]

55. Ishikawa, T.; Aoyagi, H.; Asaka, T.; Asano, Y.; Azumi, N.; Bizen, T.; Ego, H.; Fukami, K.; Fukui, T.; Furukawa, Y.; et al. A compact X-ray free-electron laser emitting in the sub-angstrom region. Nat. Photonics 2012, 6, 540-544. [CrossRef]

56. Kang, H.S.; Min, C.K.; Heo, H.; Kim, C.; Yang, H.; Kim, G.; Nam, I.; Baek, S.Y.; Choi, H.J.; Mun, G.; et al. Hard $\mathrm{X}$-ray free-electron laser with femtosecond-scale timing jitter. Nat. Photonics 2017, 11, 708-713. [CrossRef]

57. Tschentscher, T.; Bressler, C.; Grunert, J.; Madsen, A.; Mancuso, A.P.; Meyer, M.; Scherz, A.; Sinn, H.; Zastrau, U. Photon Beam Transport and Scientific Instruments at the European XFEL. Appl. Sci. 2017, 7, 592. [CrossRef]

58. Milne, C.J.; Schietinger, T.; Aiba, M.; Alarcon, A.; Alex, J.; Anghel, A.; Arsov, V.; Beard, C.; Beaud, P.; Bettoni, S.; et al. SwissFEL: The Swiss X-ray Free Electron Laser. Appl. Sci. 2017, 7, 720. [CrossRef] 
59. Grunbein, M.L.; Nass Kovacs, G. Sample delivery for serial crystallography at free-electron lasers and synchrotrons. Acta Cryst. D Struct. Biol. 2019, 75, 178-191. [CrossRef]

60. Cheng, R. Towards an Optimal Sample Delivery Method for Serial Crystallography at XFEL. Crystals 2020, 10, 215. [CrossRef]

(c)

(C) 2020 by the author. Licensee MDPI, Basel, Switzerland. This article is an open access article distributed under the terms and conditions of the Creative Commons Attribution (CC BY) license (http://creativecommons.org/licenses/by/4.0/). 